\title{
COLLABORATIVE WRITING ACTIVITY USING GOOGLE DOCS: NON-ENGLISH MAJOR STUDENTS PERSPECTIVES AND DIFFICULTIES
}

\author{
Nurul Hidjrah Hairuddin
}

Program Studi D3 Akuntansi, Jurusan Akuntansi, Politeknik Negeri Ujung Pandang nurulhidjrahh@poliupg.ac.id

\begin{abstract}
One of the most challenging skills for non-English major students is writing an essay since they have to pay attention to the language structure and must be able to transfer their thoughts and ideas into the target language. In regard to solving this problem, regular change and development are needed in teaching English writing. One of the methods that increased to be used is collaborative writing using Google Docs. This study aims to investigate the non-English major students' perspectives and difficulties in collaborative writing through Google Docs. This study examined 22 students from a state polytechnic in Makassar who have involved in collaborative writing activity through Google Docs. A convergent parallel design was applied in this study, where the data collected by using a questionnaire which consists of closed-open-ended questions and interview. The closed-ended questions data were analyzed quantitatively using descriptive statistic with SPSS. Further, the collected data from the open-ended questions and the interview was analyzed qualitatively using a narrative method. The results show that the students have positive perspectives on collaborative writing activity through Google Docs and did not encounter many difficulties when they were involved in this activity.
\end{abstract}

Keywords: Non-English Major Students' Perspectives, Collaborative Writing Activity, Google Docs

\section{INTRODUCTION}

Nowadays, learning English is more prominent since it has been employed on many sides. Four skills of English (speaking, listening, reading, and writing) have their difficulties, but writing becomes one of the skills which should get more attention (Afifah, 2020; Hasani, 2016). In writing, the authors must have indirect competence in communication and the ability to pour down their ideas into text form. The difficulties of writing require systemic and regular thinking that need to be mastered by students (Jairos Gonye, 2012). For students who study English as a Foreign Language (EFL), writing in English is very hard. They have to pay attention to the language structure; they must 
be able to transfer their thoughts and ideas into the target language from their native language. In addition, EFL students also have significant difficulties in grammar and unity terms. Moreover, specific aspects also disclosed regarding students' writing, namely paragraph structure, misspelling of the words, and dictions (Ariyanti \& Fitriana, 2017). Considering the complexity of English writing, regular improvement is needed in English language teaching, especially in teaching English writing.

Recently, there has been an increased interest in writing exercise in language classes regarding the development of written communication and the awareness that writing activity can promote language learning, and one of the activity is collaborative writing. Storch (2011) described collaborative writing as co-writing of a text by two or more author in which these authors contribute the joint partnership in producing a text. In the collaborative writing students who are more capable will encourage unable students in a collaborative learning activity (Fong, 2012). Further, Storch (2011) stated that collaborative writing activity is effective to the teaching of language because it serves the students with a chance for language practice, discussing heir own and their peers' language use as they try to construct meaning. In addition, collaborative writing also provides the students with an opportunity to result in a greater grammatical and lexical accuracy, more accurate texts and lead to acquiring the language (Storch, 2011;
Talib \& Cheung, 2017). Thus, collaborative writing is a beneficial method to improve activeness in teaching and learning activity.

Meanwhile, technology as well as the internet, have been required in all segments, including education. The internet access has enabled educators to design teaching methods. The learning process can be more exciting with the use of technology and the internet as a medium. Collaboration and construction of knowledge could be improved through interactive technologies. Hence, using technology not only become an alternative resolution to reduce and solve the students' problem in writing but also can be used as a tool to facilitate the collaborative writing implementation since it provides various online learning tools which accommodate the studentcentred-learning (Suwantarathip \& Wichadee, 2014). One of the learning tools that can be used in conducting collaborative writing activity is Google Docs. Zhou et al., (2012) stated that Google Docs could be a useful tool that helps English lecturers to teach students how to express their thoughts and comment on the writing of their peers in order to enhance their writing skills.

Google Docs is a free online word processor that is accessible to anyone with a Gmail account to create a collaborative activity. This tool offers regular editing features and eminence in real-time collaborative writing activity. It allows users to create, edit and save their files online. Google Docs provides several 
useful features, such as several writers may edit a document at the same time, each author's changes appears instantly next to a uniquely coloured marker, and even complex editing, such as cutting and pasting, can automatically fix selected areas of text with comments, maybe clarify the decisions behind editing, or question the work of another author. These comments can be filtered and deleted until they have been identified as resolved. All comments are kept for later viewing in a separate "dialogue" folder, which can still be referred back to, a chat to the window is also available which is useful to fix issues in realtime, a complete revision history is preserved and can easily be reverted to previous versions.

Some previous studies have found and showed that technology enhances learning outcomes for students. Using technology, such as Google Docs in collaborative writing activity can help to enhance and improve the acquisition of skills and knowledge (Zhou et al., 2012). Morover, Sudrajat \& Purnawarman (2019) stated that Google Docs is a suitable tool that can be used for education purposes since the students have a positive response to the use of Google Docs in translation class. In regard to explore more about the effectiveness of using Google Docs in collaborative writing activity in English class, this study was conducted to investigate the non-English major students' perspectives and difficulties in collaborative writing activity through Google Docs.

\section{METHODS}

This study conveyed a mixed-method: qualitative and quantitative methods. The subject of this study was the 4th semester students of Accounting study program of Politeknik Negeri Ujung Pandang who studied English as Academic Purposes. A convergent parallel design was applied in this study where at the same time, the researcher conducts quantitative and qualitative items in the same step of the research process and procedures, analyze these two components separately, and interprets the findings together (Creswell, 2012). A questionnaire consists of closed and open-ended questions rated using Likert scale which used to collect data regarding accounting students' as non-native english perspectives on the collaborative writing activity through Google Docs.

A pilot study was conducted to verify the questionnaire. A sample of ten students was asked to participate in the pilot study to fill in the questionnaire. The questionnaire as a nontest instrument in this research which used to measure attitudes only needs to meet the construct validity (Sugiyono, 2017). In this research, the construct validity for the questionnaire was done by testing the instrument to the sample. If the significance value is less than $5 \%$ and $r$ count $>r$ table, it can be stated that all statements in the instrument are valid. The validity test results are as follows: 
Table 1. The Questionnaire Validity

\begin{tabular}{|c|c|c|c|}
\hline Questions & $\begin{array}{c}\text { Pearson } \\
\text { Correlation }\end{array}$ & Sig & \\
\hline q1 & .975 & .000 & valid \\
\hline q2 & .941 & .000 & valid \\
\hline q3 & .946 & .000 & valid \\
\hline q4 & .921 & .000 & valid \\
\hline q5 & .800 & .005 & valid \\
\hline q6 & .934 & .000 & valid \\
\hline q7 & .852 & .002 & valid \\
\hline q8 & .966 & .000 & valid \\
\hline q9 & .942 & .000 & valid \\
\hline q10 & .884 & .001 & valid \\
\hline
\end{tabular}

Based on the table 1, the instrument has a significance value $<5 \%$ and $r$ count $>r$ table (0.632) so it can be concluded that the instrument is valid. To establish the reliability of the questionnaire, Cronbach's Alpha was used for the entire questionnaire items with the basis of decision making is If the Cronbach's Alpha value $>0.60$, the questionnaire is reliable or consistent. Table 2 shows that the value of Cronbach alpha for the questionnaire is .978 which is higher that .60. This means that the questionnaire is reliable and will provide consistent results with all participants' response.

Table 2. Questionnaire Reliability

\begin{tabular}{|c|c|c|}
\hline $\begin{array}{c}\text { Cronbach's } \\
\text { Alpha }\end{array}$ & $\begin{array}{c}\text { N of } \\
\text { items }\end{array}$ & Keterangan \\
\hline .978 & 10 & $\begin{array}{c}\text { Reliable / } \\
\text { consistent }\end{array}$ \\
\hline
\end{tabular}

The data collection technique was included in the following setting: the students were divided into some group where each group consist of 3-4 students. They were assigned to write an argumentative essay collaboratively in their group through Google Docs for one week. After they completed their essay, the questionnaire was administered to them. To analyze the data, the closed-ended questions of the questionnaire was analyzed using SPSS while for the open-ended questions was analyzed using narrative method.

\section{FINDINGS}

\section{Non-English Major Students' Perspectives toward collaborative writing activity through Google Docs}

The collected data of the closed-ended questions were analyzed quantitatively using descriptive statistic with SPSS. Table 3 shows that the overall mean score represented the positive attitudes of the students towards the use of Google Docs (mean $=3.90$ ) in the collaborative writing process. In statement 2 , the highest score of the attitudes of the students was that Google Docs is a valuable tool in the operation of collaborative writing (mean= 4.27). The students also conveyed their positive perspectives to the statement no. 8 that the use of Google Docs in collaborative writing activities provides them with an opportunity in their community to quickly share ideas (mean= 4.09). On statement no.5, the lowest mean score was that the collaborative writing technique through Google Docs increases their confidence in writing a better essay (mean=3.55). 
Table 3. Non-English Major Students' Perspectives Toward Collaborative Writing Activity Through Google Docs

\begin{tabular}{|l|c|c|}
\hline \multicolumn{1}{|c|}{ Statement } & Mean & Std.Dev \\
\hline $\begin{array}{l}\text { 1. I enjoy completing the essay writing assignment with collaborative writing } \\
\text { activity through Google Docs }\end{array}$ & 4.23 & 1.020 \\
\hline $\begin{array}{l}\text { 2. Completing the writing task with collaborative activity through Google } \\
\text { Docs is easier than writing individually. }\end{array}$ & 3.91 & 1.065 \\
\hline 3. Google Docs is a helpful tool in collaborative writing activity. & 4.27 & .883 \\
\hline 4. In the future, I will do collaborative writing through Google Docs & 3.86 & 1.037 \\
\hline $\begin{array}{l}\text { 5. Collaborative writing activity through Google Docs increase my confidence } \\
\text { in writing a better essay. }\end{array}$ & 3.55 & .800 \\
\hline $\begin{array}{l}\text { 6. Collaborative writing activity through Google Docs promotes the exchange } \\
\text { of knowledge and experience. }\end{array}$ & 4.00 & 1.155 \\
\hline $\begin{array}{l}\text { 7. Collaborative writing activity through Google Docs improves my English } \\
\text { writing skills. }\end{array}$ & 3.59 & .796 \\
\hline $\begin{array}{l}\text { 8. Collaborative writing activity through Google Docs gives me an } \\
\text { opportunity to share ideas easily in my group. }\end{array}$ & 4.09 & 1.269 \\
\hline $\begin{array}{l}\text { 9. Collaborative writing activity through Google Docs helps me to gain useful } \\
\text { feedback. }\end{array}$ & 3.91 & 1.109 \\
\hline $\begin{array}{l}\text { 10. Collaborative writing activity through Google Docs promotes my critical } \\
\text { thinking. }\end{array}$ & 3.68 & .716 \\
\hline & 3.90 & .990 \\
\hline
\end{tabular}

Students' difficulties toward collaborative activity through Google Docs

The collected data of the open-ended question of the questionnaire and interview were analyzed qualitatively using the narrative method. Table 4 shows that poor internet connection is the problem most faced by students $(36 \%)$, followed by about $18 \%$ of the total sample who are still confused about using Google docs. However, $22 \%$ of the sample stated that they did not face any obstacles when engaging in collaborative activities.

Table 4. Non-English major students' difficulties toward collaborative activity through Google Docs

\begin{tabular}{|c|l|c|}
\hline No & \multicolumn{1}{|c|}{ Area } & Frequency (\%) \\
\hline 1 & Internet connection is unstable & $8(36,36 \%)$ \\
\hline 2 & No difficulties & $5(22,73 \%)$ \\
\hline 3 & Still confuse on how to use Google Docs & $4(18,18 \%)$ \\
\hline 4 & There are group member who are not active & $2(9,09 \%)$ \\
\hline 5 & The menu display is different from Microsoft word & $1(4,55 \%)$ \\
\hline 6 & It is hard to come up with ideas & $1(4,55 \%)$ \\
\hline 7 & Unsystematic discussion $\quad$ Total & $1(4,55 \%)$ \\
\hline \multicolumn{2}{|c|}{} \\
\hline
\end{tabular}

The focus of the interview was to provide more information further into the effectiveness of implementing Google Docs with the collaborative method of writing. Random 
respondents were questioned after administering the questionnaire and asked about the experience they had experienced.

All the participants expressed their optimistic feelings about combining collaborative writing practices with Google Docs in the first question of the interview. When the participants were asked about to what extent, they claimed that collaborative writing activity through Google Docs was helpful and interesting as the second question for the interview. They said they feel confused in the beginning and seem to be unable to use Google Docs properly because it was their first practice. In the end, however, they found it was not complicated and straightforward to use. They could engage with each other and provide feedback on each other writing through left comments in the comment section, which is great because they have corrected their errors at the same time. Indeed, they could examine whether their argumentative essay structure was correct or not

The students were asked about the difficulties they faced while using Google Docs in the third interview question. They said that since it was their first time, they only had difficulties at the beginning of the procedure, The poor communication causes them unable to communicate in real-time within their group. This suggests that when they used Google Docs for group writing tasks, the students did not face any difficulties; they only had technological issues due to inadequate internet connectivity.
The last question in the interview was the opinion of the students as to whether Google Docs could be included in the next course or not. Both respondents indicated that they believe that Google docs will be used again because this strategy helps to complete their mission.

\section{DISCUSSION}

This study was conducted to evaluate the perspectives and difficulties of non-English major students regarding collaborative writing using Google Docs. The students shared positive views on collaborative activity through Google Docs (mean=3.90) as a result of the questionnaire and interview. The findings of the questionnaire showed that the students' high degree of attitude was in the statement that Google Docs is a valuable tool for collaborative writing tasks (mean $=4.27$ ). The findings were found to be in accordance with some previous studies in that Google Docs is a useful tool in collaborative writing activity (Suwantarathip \& Wichadee, 2014; Zhou et al., 2012). The students also expressed their positive attitude to the statement no. 8 that using Google Docs in collaborative writing activities offers them a chance to exchange ideas easily in their community $($ mean $=4.09)$. This is probably because collaborative writing activity through Google Docs serves the students with a chance for language practice, discussing heir own and their peers' language use as they try to construct meaning (Storch, 2011). In addition, collaborative writing also provides the students 
with an opportunity to result in a greater grammatical and lexical accuracy, more accurate texts and lead to acquiring the language (Storch, 2011; Talib \& Cheung, 2017). The lowest mean score on statement no.5 was that the method of collaborative writing using Google Docs boosts their faith in writing a better essay (mean=3.55). More insight into the incorporation efficacy of collaborative writing and Google docs was revealed from the interview findings. Participants were questioned about their questionnaire responses. Since it was their first encounter, they indicated that they were worried about using Google Docs at the outset. At the end of the day, though, they found it was not difficult and easy to use. Via the comment section, they will participate together and provide input on others writing that is nice because at the same time they corrected their mistakes. They should also analyze whether or not their argumentative essay form was correct. Participants also revealed that while they used Google Docs for collaborative writing activities, they did not face any problems; because of restricted internet access, they only had technical problems.

\section{CONCLUSION}

The main objective of this study was to examine the non-english major students' perspectives and difficulties toward collaborative writing activity through Google Docs. The findings of this study revealed that the students had positive attitudes on the use of Google Docs in a collaborative writing activity. They confirmed that they did not face many difficulties when involved in the activity; they just had technical problems because of limited internet connectivity and feel confused in the beginning of the activity since it was their first experience.

\section{REFERENCES}

Afifah, D. (2020). Collaborative Writing Technique Effect on The Students' Writing Achievement. LangEdu Journal, January.

Ariyanti, A., \& Fitriana, R. (2017). EFL Students' Difficulties and Needs in Essay Writing. 158(Ictte), 111-121. https://doi.org/10.2991/ictte-17.2017.4

Creswell, J. W. (2012). Education Research: Planning, Conducting, and Evaluating Quantitative and Qualitative Reserach (Fourth Edi). Pearson.

Fong, L. S. (2012). Students in the Production of Reports. 4, 396-407.

Hasani, A. (2016). Enhancing Argumentative Writing Skill through Contextual Teaching and Learning. Educational Research and Reviews, 11(16), 1573-1578. https://doi.org/10.5897/ERR2016.2806

Jairos Gonye. (2012). Academic writing challenges at Universities in Zimbabwe: A case study of great Zimbabwe University. International Journal of English and Literature, 3(3), 71-83. https://doi.org/10.5897/ijel11.092

Storch, N. (2011). Collaborative writing in L2 contexts: Processes, outcomes, and future directions. Annual Review of Applied Linguistics, 31, 275-288. https://doi.org/10.1017/S026719051100 0079 
Sudrajat, W. N. A., \& Purnawarman, P. (2019). Students' Perceptions on the Use of Google Docs as an Online Collaborative Tool in Translation Class. Lingua Cultura, 13(3),

209. https://doi.org/10.21512/lc.v13i3.5969

Sugiyono. (2017). Metode Penelitian Kombinasi (Mixed Methods) (Sutopo (ed.); 9th ed.). Alfabeta.

Suwantarathip, O., \& Wichadee, S. (2014). The effects of collaborative writing activity using Google docs on students' writing abilities. Turkish Online Journal of Educational Technology, 13(2), 148-156.
Talib, T., \& Cheung, Y. L. (2017). Collaborative Writing in Classroom Instruction: A Synthesis of Recent Research. The English Teacher, 46 (2), August, 43-57.

Zhou, W., Simpson, E., \& Domizi, D. P. (2012). Google Docs in an Out-of-Class Collaborative Writing Activity. International Journal of Teaching and Learning in Higher Education, 24(3), 359375. 